\title{
Research on Building Method of Organizational Process Performance Model in Project Management
}

\author{
Dexin Huang \\ CASIC-CQC Software Testing and Evaluation Technology (Beijing) Corporation, Ltd. 21-story 02, No.119 \\ Shuiyin Road Star King Building, Yuexiu District, Guangzhou, China.
}

878512868@qq.com

Keywords: Organizational Process Performance Model, CMMI, Project Management.

\begin{abstract}
This paper proposes a new building method of organizational process performance model, which can achieve better quantitative project management and active project control level by combined with the actual situation and follow the CMMI specifications.
\end{abstract}

\section{Introduction}

Based on the organization process performance management mode in CMMI5 high maturity field. the business goals of organizations and quantitative goals of projects are clearly reflected by establishing the organizational process performance baselines and models. The multi-level relationship between progress quantitative monitor and program performance data management is better reflected. The quantitative program management is realized. The active management and control of grid enterprise information project is achieved.

\section{The procedure of modeling}

Definition: process performance model: This is a parametric model for predicting future results based on historical data

The forecast objectives are determined: According to the organization business goals, the past organizational process improvement recommendations and the capability of current organizational execution process, the forecast goals are determined and recorded as Y.

The forecast model is chosen: the multiple linear regression model $\mathrm{Y}=\mathrm{a}+\mathrm{b}_{1} * \mathrm{x}_{1}+\mathrm{b}_{2}{ }^{*} \mathrm{x}_{2}+\ldots \ldots$ $+b_{n}{ }^{*} x_{n}$ is applied in this essay.

The factor $\mathrm{X}$ affecting target $\mathrm{Y}$ is selected through brainstorming and fishbone diagram.

Acquisition of the raw data.

Stability analysis on target $\mathrm{Y}$ and parameter $\mathrm{X}$ is performed: normal test based on minitab statistic tool is conducted. target $\mathrm{Y}$ is ensured to be table through normal test on the results of this step.

The correlation analysis: The correlation analysis is conducted to parameter $\mathrm{X}$ and target $\mathrm{Y}$.

The regression analysis is performed on target $\mathrm{Y}$ and parameter $\mathrm{X}$ applying regression model built by minitab.

\section{Case analysis}

Higher software quality requirements for the construction of information system was proposed by an enterprise in 2017. The software quality can be quantified by controlling the number of defects in the acceptance test. It is assumed that $\mathrm{Y}$ is defined as "defect density of acceptance test".

Adopting brainstorm method, the relevant indicators of $\mathrm{Y}$ was determined, which includes " $\mathrm{X}_{1}=$ module scale", " $\mathrm{X}_{2}=$ coding workload", " $\mathrm{X}_{3}=$ unit test defect density", " $\mathrm{X}_{4}=$ integrated test defect density", " $\mathrm{X}_{5}=$ system test defect density", and " $\mathrm{X}_{6}=$ trial operation".

The information system project data of the company was collected. A data table was formed to 
prepare for modeling by establishing the baseline. It is shown in the following table.

Table 1: Data table

\begin{tabular}{|c|l|r|r|r|r|c|c|c|}
\hline $\begin{array}{c}\text { Project } \\
\text { name }\end{array}$ & \multicolumn{1}{|c|}{$\begin{array}{c}\text { Module } \\
\text { name }\end{array}$} & $\begin{array}{c}\text { Module } \\
\text { size }\end{array}$ & $\begin{array}{c}\text { Module } \\
\text { workload }\end{array}$ & $\begin{array}{c}\text { Unit test } \\
\text { defect } \\
\text { density }\end{array}$ & $\begin{array}{c}\text { Integrated } \\
\text { test defect } \\
\text { density }\end{array}$ & $\begin{array}{c}\text { System } \\
\text { test } \\
\text { defect } \\
\text { density }\end{array}$ & $\begin{array}{c}\text { Trial } \\
\text { operation } \\
\text { defect } \\
\text { density }\end{array}$ & $\begin{array}{c}\text { Acceptance } \\
\text { test defect } \\
\text { density }\end{array}$ \\
\hline $\begin{array}{c}\text { Electricity } \\
\text { XX } \\
\text { document } \\
\text { manage } \\
\text { system }\end{array}$ & $\begin{array}{l}\text { Document } \\
\text { portal }\end{array}$ & 12.246 & 114 & 1.307 & 1.062 & 1.388 & 0.735 & 0.653 \\
\hline $\begin{array}{l}\text { System } \\
\text { manageme } \\
\text { nt }\end{array}$ & 13.929 & 130 & 1.149 & 0.862 & 1.723 & 0.718 & 0.574 \\
\hline $\begin{array}{l}\text { Safety } \\
\text { supervision } \\
\text { intelligent } \\
\text { information } \\
\text { system of } \\
\text { XX Bureau }\end{array}$ & $\begin{array}{l}\text { Security } \\
\text { check data } \\
\text { analysis }\end{array}$ & 14.011 & 140 & 1.856 & 1.142 & 2.855 & 0.714 & 0.928 \\
\cline { 2 - 9 } & Inspection & 16.246 & 157 & 0.985 & 0.800 & 1.231 & 0.554 & 0.492 \\
\hline
\end{tabular}

Normal tests for "module scale", "module workload", "unit test", "integration test", "system test", "trial operation" and "acceptance test" are conducted respectively applying minitab statistical tools.

Correlation test is shown as the following table.

Table 2: Result of correlation test

\begin{tabular}{|l|l|l|l|}
\hline \multirow{4}{*}{ Integrated test defect density } & $\begin{array}{l}\text { Unit test defect } \\
\text { density }\end{array}$ & $\begin{array}{l}\text { Integrated test } \\
\text { defect density }\end{array}$ & System test defect density \\
\cline { 2 - 4 } & 0.265 & & \\
\cline { 2 - 4 } & 0.153 & & \\
\hline \multirow{2}{*}{ System test defect density } & 0.649 & 0.197 & \\
\cline { 2 - 4 } & 0.000 & 0.296 & -0.000 \\
\hline \multirow{2}{*}{ Trial operation defect density } & 0.678 & 0.067 & 0.676 \\
\cline { 2 - 4 } & 0.682 & 0.646 & 0.882 \\
\hline \multirow{2}{*}{ Acceptance test defect density } & 0.863 & 0.291 & 0.000 \\
\cline { 2 - 4 } & 0.000 & 0.118 & \\
\hline
\end{tabular}

0.8-1.0 is distinct correlation, $0.6-0.8$ is strong correlation, 0.4-0.6 is moderate correlation and 0.2-0.4 is weak correlation, according to the Pearson's coefficient. According to the correlation analysis above, it can be determined that the correlation between the number of defects in "unit test" and the number of defects in "acceptance test" is 0.863 . The correlation between the number of defects in "system test" and the number of defects in "acceptance test" is 0.882 . These are strong correlation. These two factors can be used to establish the regression model.

The data table after determining the correlation is shown as the following table.

Table 3: Data table after determining the correlation

\begin{tabular}{|c|l|c|c|c|}
\hline Project name & Module name & $\begin{array}{c}\text { Unit test } \\
\text { defect } \\
\text { density }\end{array}$ & $\begin{array}{c}\text { System test } \\
\text { defect } \\
\text { density }\end{array}$ & $\begin{array}{c}\text { Acceptance test defect } \\
\text { density }\end{array}$ \\
\hline $\begin{array}{c}\text { Electricity XX System } \\
1\end{array}$ & Document portal & 1.307 & 1.388 & 0.653 \\
\cline { 2 - 5 } & System management & 1.149 & 1.723 & 0.574 \\
\hline$\cdots \cdots$ & $\cdots \cdots$ & $\cdots \cdots$ & $\cdots \cdots$ & $\cdots \cdots$ \\
\hline \multirow{2}{*}{$\begin{array}{c}\text { Electricity XX System } \\
\text { n }\end{array}$} & $\begin{array}{l}\text { Security check data } \\
\text { analysis }\end{array}$ & 1.856 & 2.855 & 0.928 \\
\cline { 2 - 5 } & Inspection report & 0.985 & 1.231 & 0.493 \\
\hline
\end{tabular}

The regression equation is established applying the minitab tool.

regression analysis: acceptance test defect density (Defects/KLOC) and unit test defect density(Defects/KLOC), system test defect density(Defects/KLOC) 
The regression equation is acceptance test defect density $($ Defects/KLOC) $=0.117+0.196$ acceptance test defect density (Defects/KLOC) +0.148 system test defect density(Defects/KLOC) .

Table 4: regression analysis result

\begin{tabular}{|l|l|l|l|l|}
\hline Independent variable & Coefficient & $\begin{array}{l}\text { Standard error of } \\
\text { coefficient }\end{array}$ & $\mathrm{T}$ & $\mathrm{P}$ \\
\hline Constant & 0.11712 & 0.04962 & 2.36 & 0.026 \\
\hline $\begin{array}{l}\text { unit test defect } \\
\text { density(Defects/KLOC) }\end{array}$ & 0.19569 & 0.07273 & 2.69 & 0.012 \\
\hline $\begin{array}{l}\text { system test defect } \\
\text { density(Defects/KLOC) }\end{array}$ & 0.14844 & 0.04228 & 3.51 & 0.002 \\
\hline
\end{tabular}

The $\mathrm{P}$ value is got through $\mathrm{T}$ test on the coefficients. The $\mathrm{P}$ value represents the correlation of $\mathrm{X}$ value and $\mathrm{Y}$ value. The greater the $\mathrm{P}$ value, the weaker the correlation. The $\mathrm{P}$ value is less then 0.05 .

$\mathrm{S}=0.0630908 \mathrm{R}-\mathrm{Sq}=82.5 \% \mathrm{R}-\mathrm{Sq}$ (modified) $=81.2 \%$

$\mathrm{R}-\mathrm{Sq}$ represents these predictive variables account for a total of $82.5 \%$ of the variance $\mathrm{S}$ of the acceptance test defect density.

This value represents the confidence level of the model, and the higher the value, the better the confidence.

The result of variance analysis:

Table 5: Result of variance analysis

\begin{tabular}{|l|l|l|l|l|l|}
\hline Source & $\begin{array}{l}\text { Degrees } \\
\text { of } \\
\text { freedom }\end{array}$ & SS & MS & F & P \\
\hline Regression & 2 & 0.50641 & 0.25320 & 63.61 & 0.000 \\
\hline Residual error & 27 & 0.10747 & 0.00398 & & \\
\hline Total & 29 & 0.61388 & & & \\
\hline
\end{tabular}

\begin{tabular}{|l|l|l|}
\hline Source & Degrees of freedom & Seq SS \\
\hline $\begin{array}{l}\text { unit test defect } \\
\text { density(Defects/KLOC) }\end{array}$ & 1 & 0.45735 \\
\hline $\begin{array}{l}\text { system test defect } \\
\text { density(Defects/KLOC) }\end{array}$ & 1 & 0.04906 \\
\hline
\end{tabular}

Seq SS: Sum of squares between groups;

MS: This is the mean squared of the SS over the degrees of freedom

$\mathrm{F}=$ factor, MS/error(0.25320/0.00398=63.61).This value can be compared with the critical $\mathrm{F}$ found in the table to determine whether a factor is significant.

$\mathrm{P}$ : This is used to test the correlation of the factor. If the $\mathrm{P}$ value is lower than 0.05 , the correlation of the factor is strong.

Abnormal observations:

Table 6: Abnormal observations

\begin{tabular}{|c|c|c|c|c|c|c|}
\hline \multirow{2}{*}{ observations } & \multirow{2}{*}{$\begin{array}{c}\text { unit test defect } \\
\text { density(Defects/K } \\
\text { LOC) }\end{array}$} & $\begin{array}{c}\text { acceptance test } \\
\text { defect density } \\
\text { (Defects/KLOC) }\end{array}$ & \multicolumn{2}{|c|}{ fitted value } & \multicolumn{2}{|c|}{ standardized } \\
\cline { 4 - 6 } & value & $\begin{array}{c}\text { Standard } \\
\text { error }\end{array}$ & residual & residual \\
\hline 30 & 0.73 & 0.7305 & 0.5010 & 0.0296 & 0.2294 & $\begin{array}{c}4.12 \mathrm{R}(\mathrm{R} \\
\text { indicates that the } \\
\text { observed value } \\
\text { contains large } \\
\text { standardized } \\
\text { residuals }\end{array}$ \\
\hline
\end{tabular}

The causes of the abnormal data are analyzed. The acceptance test defect density calculated according to the regression equation is 0.495188 . The actual acceptance test defect density is 0.73 , which is higher than the value calculated using the regression equation. The reason is that the module 
configuration file was not fully configured by the new implementer. This resulted in the abnormal part of the function points, therefore the acceptance test density is higher.

Conclusion: acceptance test defect density (Defects/KLOC) $=0.117+0.148$ system test defect density(Defects/KLOC)+0.196acceptance test defect density (Defects/KLOC) .The model can be used in similar projects to estimate the enterprise target value and regression simulation next year.

\section{Summary}

The quantitative goals of the business and projects of the organization can be clearly reflected through the establishment of the organizational process performance baseline and model. The quantitative management of enterprise informatization projects can be realized. The model can better practicability after continuous evolution and improvement.

\section{References}

[1] Xiaoqun. He, Wenqin. Liu. The application of regression analysis[M]. Beijing: China Renmin University Press.2001. (In Chinese)

[2] William D. Berry. Basis for linear regression analysis[M]. Shanghai: Shanghai people's publishing house.2011. (In Chinese)

[3] Huali. Wang. A case study of multiple linear regression analysis[J]. Science and technology information.2014(29):22-22.

[4] Jianwen. Yuan. Econometric experiment[M]. Beijing: Science press.2002.(In Chinese)

[5] Jinmin. Su, Shenyong. Ruan, Yongli. Wang. MATLAB engineering mathematics[M]. Beijing: Electronics industry press.2005.(In Chinese)

[6] Rilei. Zhao. Hand teaching of performance management: model, method, case and practice[M]. Beijing: Electronics industry press.2016. (In Chinese) 